\title{
Karakteristik Marshall Keramik Sebagai Agregat Halus Dan Filler Pada Campuran Hot Roller Sheet (HRS)
}

\author{
Ulwiyah Wahdah Mufassirin Liana ${ }^{1}$, Santi Yatnikasari ${ }^{2}$, Muhammad Noor Asnan ${ }^{3}$ \\ Fakultas Sains dan Teknologi, Universitas Muhammadiyah Kalimantan Timur ${ }^{1,2,3}$ \\ Email:uwm216@umkt.ac.id ${ }^{1}$, sy998@umkt.ac.id ${ }^{2}$, mna985@umkt.ac.id ${ }^{3}$ \\ DOI: http://dx.doi.org/10.31869/rtj.v5i1.2832
}

\begin{abstract}
Penelitian ini mengenai pemanfaatan bahan sisa keramik pada pemasangan lantai rumah sebagai agregat halus dan filler dalam pembuatan lapis perkerasan aspal. Sebagai bahan agregat halus dan filler, keramik dicampur dengan Semen Portland dengan komposisi tertentu. Hal ini dilakukan untuk meningkatkan daya ikat antar butiran keramik. Penelitian ini dilakukan untuk mengetahui penggunaan keramik sebagai dan agregat halus dan filler pada campuran HRS-WC terhadap karakteristik stabilitas, flow, density, VITM, VFWA, VMA, Marshall Quotient dan Immersion Test. Tahap pertama dimulai dari pemeriksaan bahan aspal dan agregat menggunakan spesifikasi Bina Marga. Tahap kedua membuat benda uji untuk mencari kadar aspal optimum dengan filler abu batu dengan kadar aspal 4\%, 4,5\%, 5\%, 5,5\%, dan 6\%. Tahap ketiga dilakukan pengujian Marshall standar dan Immersion Test pada variasi agregat halus dan filler dengan kadar yaitu $0 \%$ keramik, 25\% keramik, 50\% keramik, 75\% keramik dan 100\% keramik dengan menggunakan kadar aspal optimum. Dari hasil penelitian dapat disimpulkan bahwa semakin banyak penambahan keramik akan menurunkan nilai stabilitas, Marshall Quotient, VITM dan VMA dan menaikkan nilai flow, density dan VFWA. Keramik dapat digunakan sebagai agregat halus dan filler dalam pembuatan lapis perkerasan HRS dengan variasi kadar 25\% keramik.
\end{abstract}

Keywords: keramik, filler, Marshall Quotient

\section{PENDAHULUAN}

Pertumbuhan ekonomi mengakibatkan peningkatan volume transportasi yang harus diimbangi dengan pembangunan jalan yang berkualitas. Untuk meningkatkan pembangunan jalan yang baik, aman dan nyaman dibutuhkan material perkerasan yang memiliki kualitas yang baik pula. Banyak faktor yang dapat menyebabkan rusaknya perkerasan lentur, namun yang paling sering ditemukan adalah kerusakan yang disebabkan oleh kualitas material perkerasan. Kualitas material yang digunakan dapat mempengaruhi kekuatan dan daya tahan perkerasan terhadap beban lalu lintas selama umur rencana. Apabila kualitas material yang digunakan tidak sesuai dengan yang direncanakan maka akan menyebabkan perkerasan rusak sebelum umur rencana (Nikmatul, 2017).

Lapisan tipis aspal beton (Lataston) atau dikenal dengan nama Hot Rolled Sheet (HRS) adalah suatu lapisan atas perkerasan pada konstruksi jalan raya, yang terdiri dari bitumen, agregat kasar, agregat halus dan filler (bahan pengisi) yang dicampurkan dan dipadatkan pada suhu tertentu. HRS-WC merupakan lapisan atas perkerasan dengan ketebalan 2.5-3 cm untuk lalu lintas sedang
(Sukirman, 1999) Perkerasan dengan HRS cocok diterapkan di Indonesia karena memiliki kelenturan yang tinggi dan tahan terhadap pelelehan mengingat Indonesia adalah negara beriklim tropis. Namun kualitas HRS-WC perlu ditingkatkan melalui spesifikasi baru dan jenis

material yang digunakan harus memiliki sifat fisik dan mekanik yang baik (Nikmatul, 2017). Filler dapat ada dan juga dapat tidak ada dalam suatu perkerasan, namun fungsi perkerasan akan semakin optimal apabila ditambahkan filler. Filler dapat berfungsi sebagai pengisi rongga yang terjadi antar agregat.

Pada penelitian ini, bahan tambahan pada agregat halus dan filler adalah keramik. Keramik adalah suatu bentuk dari tanah liat yang telah mengalami proses pembakaran. Terdapat 2 jenis keramik, yaitu keramik dengan lapisan glazur dan keramik tanpa lapisan glazur. Keramik jenis glazur memiliki sifat lebih padat, tahan api dan air, tidak berpori, mudah dibersihkan dan lebih mudah ditumbuk (Kalbu, 2020). Selain itu menurut (Laia, Sandro dkk, 2016) bahan mentah keramik bersifat keras, ringan, tegar, tahan api dan korosi. Limbah keramik adalah sisa 
keramik dari pemasangan keramik pada suatu bangunan, atau bisa juga keramik yang tidak lolos standar produksi keramik dan Jika tidak diolah dengan benar akan menjadikan masalah lingkungan (Revisdah, 2018), sehingga dibutuhkan pemanfaatan limbah keramik agar dapat memberikan nilai ekonomis. Nilai stabilitas pada Lapisan Aspal Beton (LASTON) menunjukan bahwa ada perbedaan penggunaan bahan pengisi Serbuk Keramik terhadap parameter marshal (Arief, 2013). Pada penelitian ini keramik yang digunakan adalah keramik sisa pemasangan lantai rumah yang berbahan glazur dan diharapkan dapat meningkatkan kekuatan campuran Lapisan tipis aspal beton (LATASTON).

\section{METODE PENELITIAN}

Metode penelitian yang dilakukan adalah metode eksperimental yang dilakukan di Laboratorium Program Studi Teknik Sipil, Fakultas Sains dan Teknologi, Universitas Muhammadiyah Kalimantan Timur.

\section{Bahan yang Digunakan}

Bahan tambahan pada agregat halus dan filler yang digunakan dalam penelitian ini adalah tumbukan keramik. Agregat kasar dan agregat halus berasal dari daerah Palu dan aspal keras AC 60/70.

\section{Perencanaan dan Pembuatan Benda Uji}

Jenis campuran beton aspal yang digunakan adalah lapis tipis aspal beton Hot Rolled Sheet (HRS) dengan proporsi gabungan antara gradasi agregat Bina Marga dan gradasi dari Central Quality Control and Monitoring Unit, 1998. Gradasi agregat dapat dilihat pada Tabel 1 dan Gambar 1

Pada penelitian ini, tahap pertama yang dilakukan adalah menguji semua bahan dasar untuk campuran beton aspal yang terdiri dari aspal, agregat kasar, agregat halus dan bahan pengisi (filler).

Tahap kedua, menentukan kadar aspal optimum dari benda uji yang memiliki komposisi campuran yaitu aspal ditambah agregat dan filler. Variasi kadar aspal yang digunakan terdiri dari kadar aspal 4\%, 4,5\%, $5 \%$, 5,5\%, dan 6\%. Semua kadar aspal masing-masing menggunakan filler $100 \%$ abu batu.

Tahap ketiga, dengan menggunakan kadar aspal optimum, kemudian dibuat 5 variasi kadar agregat halus dan filler dengan rincian sebagai berikut, menggunakan $0 \%$ keramik,
25\% keramik, menggunakan 50\% keramik, menggunakan $75 \%$ keramik, dan menggunakan $100 \%$ keramik. Berat total agregat halus dan filler yang digunakan pada pengujian variasi yaitu $2 \%$ dari berat total agregat yang sudah dikurangi dengan berat kadar aspal aspal optimum. Total agregat halus dan filler yang digantikan adalah agregat yang tertahan saringan no.50, no.100 dan no.200.

Jumlah benda uji yang dibutuhkan untuk varisi kadar aspal sebanyak 15 buah, jumlah benda uji untuk variasi filler sebanyak 15 buah, jumlah benda uji untuk immersion test 15 buah, maka keseluruhan benda uji adalah 45 buah.

Pengujian Marshall dilakukan untuk mendeskripsikan kinerja campuran HRS sehingga diperoleh nilai stabilitas, kelelehan (flow), Marshall Quotient (MQ), Void in The Mixture (VITM), Void in Mineral Agregate (VMA), dan Void Filled with Asphalt (VFWA) sesuai dengan SNI 06-2489-1991.

Tabel 1 Gradasi Agregat Campuran

\begin{tabular}{|l|l|l|l|l|l|}
\hline \multicolumn{2}{|l|}{$\begin{array}{l}\text { Ukuran } \\
\text { saringan }\end{array}$} & \multicolumn{2}{l|}{$\begin{array}{l}\text { Spesifikasi } \\
\text { \% Lolos } \\
\text { Saringan }\end{array}$} & $\begin{array}{l}\text { Gradasi } \\
\text { Ideal }\end{array}$ & $\begin{array}{l}\text { Gradasi } \\
\text { Digunakan }\end{array}$ \\
\hline inchi & $\mathrm{mm}$ & Min & Max & & \\
\hline $3 / 4^{\prime \prime}$ & 19.05 & 97 & 100 & 98.5 & 98.5 \\
\hline $1 / 2^{\prime \prime}$ & 12.7 & 70 & 100 & 85 & 85 \\
\hline $3 / 8^{\prime \prime}$ & 9.525 & 58 & 80 & 69 & 69 \\
\hline$\# 4$ & 6.35 & 50 & 60 & 55 & 55 \\
\hline$\# 8$ & 3.175 & 46 & 60 & 53 & 53 \\
\hline$\# 30$ & 0.8467 & 16 & 60 & 38 & 38 \\
\hline$\# 50$ & 0.508 & 10 & 48 & 29 & 28.275 \\
\hline$\# 100$ & 0.254 & 3 & 26 & 14.5 & 13.775 \\
\hline$\# 200$ & 0.127 & 2 & 8 & 5 & 4.125 \\
\hline
\end{tabular}

Sumber: Bina Marga, 2009 dan Hasil

Penelitian, 2021 


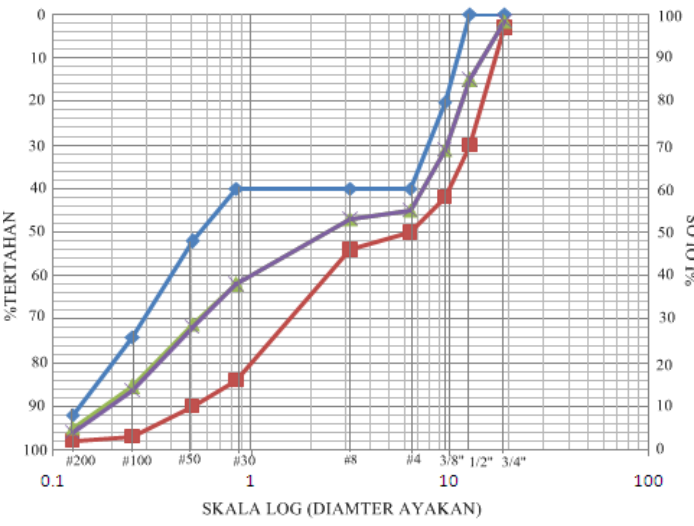

Gambar 1 Grafik Gradasi Agregat Ideal dan Gradasi yang Digunakan dalam Penelitian

Sumber: Bina Marga, 2009 dan Hasil Penelitian, 2021

\section{HASIL DAN PEMBAHASAN}

Hasil pengujian campuran untuk nilai-nilai parameter Marshall dapat dilihat pada Gambar 3 sampai Gambar 9.

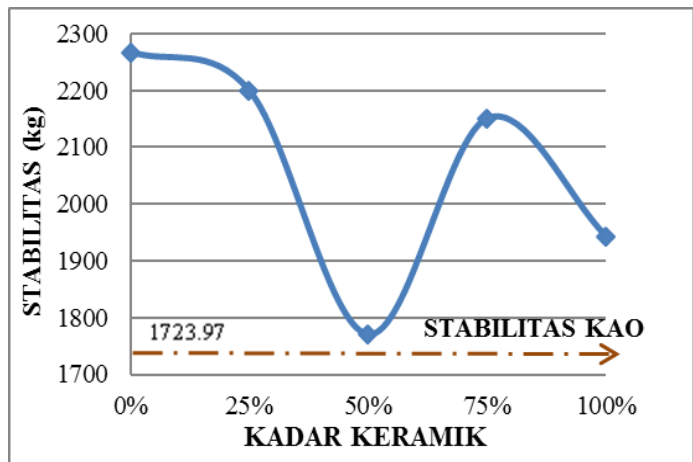

Gambar 3 Grafik Hubungan Variasi Kadar Keramik dengan Nilai Stabilitas

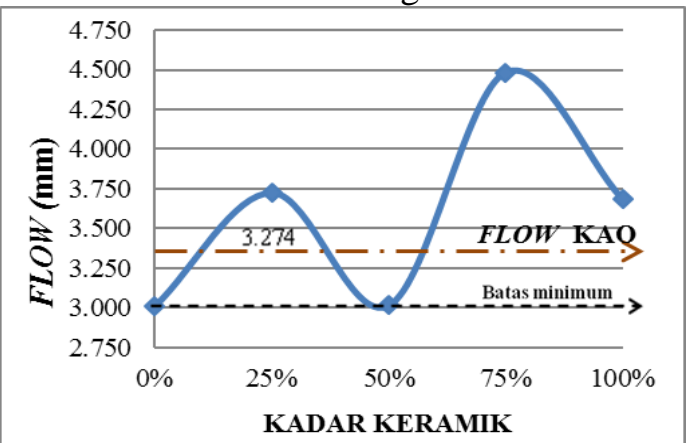

Gambar 4 Grafik Hubungan Variasi Kadar Keramik dengan Nilai Flow

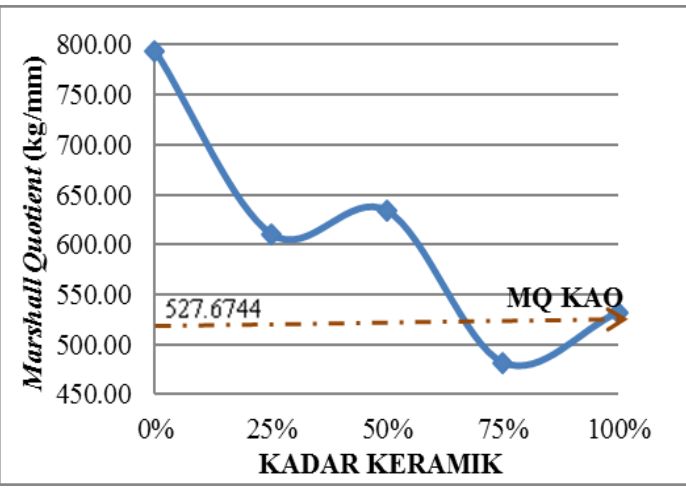

Gambar 5 Grafik Hubungan Variasi Kadar Keramik dengan Nilai MQ

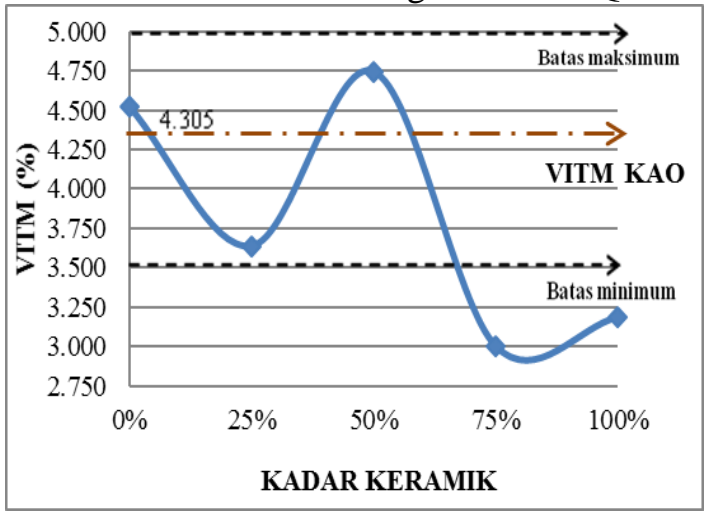

Gambar 6 Grafik Hubungan Variasi Kadar Keramik dengan Nilai VITM

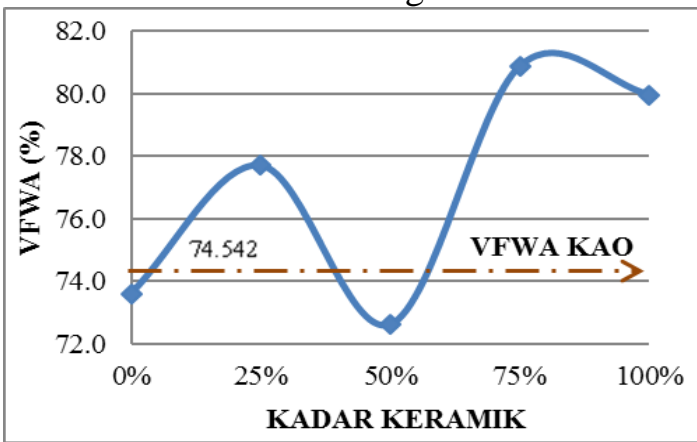

Gambar 7 Grafik Hubungan Variasi Kadar Keramik dengan Nilai VFWA

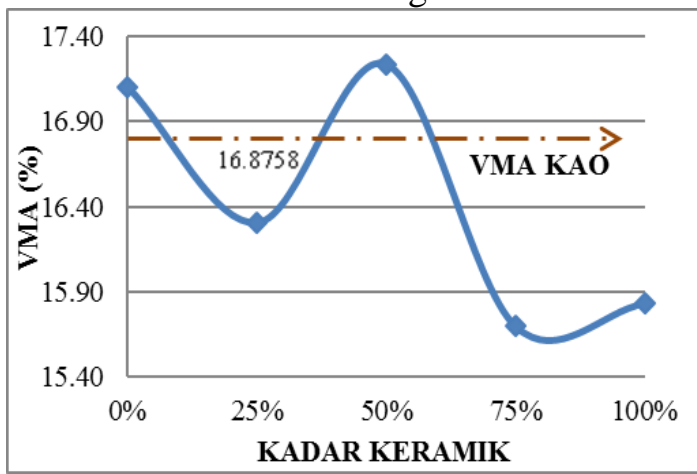

Gambar 8 Grafik Hubungan Variasi Kadar Keramik dengan Nilai VMA 


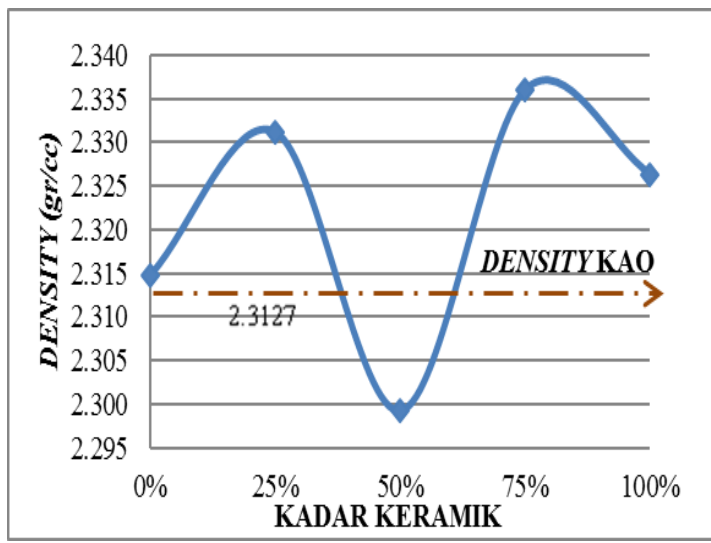

Gambar 9 Grafik Hubungan Variasi Kadar Keramik dengan Nilai Density

Berdasarkan pengujian, keramik memiliki nilai berat jenis sebesar 1,77 dan berat jenis debu batu sebesar 2,64. Dengan berat campuran yang sama, maka keramik memiliki volume yang lebih besar daripada volume debu batu. Penambahan keramik yang semakin banyak, menyebabkan volume campuran akan semakin besar dan agregat akan penuh di dalam campuran beton aspal dan jumlah rongga udara dalam campuran berkurang. Keramik memiliki nilai penyerapan air yang cukup besar yaitu $\leq 5 \%$, sehingga semakin banyak keramik yang ditambahkan maka semakin banyak aspal yang diserap oleh keramik dan mengakibatkan jumlah aspal untuk mengikat agregat berkurang sehingga daya ikat antar agregat akan berkurang dan menyebabkan agregat mudah lepas.

Berdasarkan grafik pada Gambar 3, dapat dilihat bahwa semakin banyak jumlah keramik yang ditambahkan akan menurunkan stabilitas beton aspal. Keramik mampu meningkatkan daya dukung beton aspal. Hal ini disebabkan karena adanya perbedaan nilai berat jenis agregat halus dan filler yang digunakan. Stabilitas yang cukup mampu mendukung beban lalu lintas yang melewatinya tanpa mengalami deformasi permanen dan deformasi plastis selama umur rencana (Laia, Sandro dkk, 2016).

Berdasarkan Gambar 4, penambahan keramik menghasilkan nilai flow yang semakin meningkat. Hal ini disebabkan karena keramik bersifat menyerap aspal, sehingga semakin banyak jumlah keramik yang ditambahkan maka semakin banyak aspal yang diserap oleh keramik. Semakin banyak keramik yang ditambahkan dengan jumlah aspal yang sama, maka semakin tipis aspal yang menyelimuti agregat dan agregat akan mudah lepas. Nilai flow yang tinggi menghasilkan campuran yang cenderung plastis, sehingga mudah berubah bentuk jika terlalu banyak menerima beban (Arief, 2013).

Pada Gambar 5, nilai Marshall Quotient menurun seiring dengan penambahan jumlah keramik. Menurunnya nilai MQ mengakibatkan campuran semakin plastis, karena daya dukungnya menurun dan kelelehan campuran mengingkat. Campuran beton aspal yang baik digunakan adalah campuran yang kuat dan lentur (Sukirman, Beton Aspal Campuran Panas, 2012). Untuk mendapatkan campuran beton aspal yang kuat dan lentur, dibutuhkan campuran beton aspal yang memiliki stabilitas dan flow (kelelehan) yang tinggi.

Berdasarkan Gambar 6, Nilai Void in the Total Mix (VITM) akan menurun seiring dengan penambahan keramik. Campuran beton aspal dengan variasi kadar 75\% keramik dan $100 \%$ keramik memiliki rongga udara terlalu sedikit, dapat dilihat dari nilai VITM untuk kedua campuran tersebut tidak memenuhi syarat spesifikasi Bina Marga 2010 dan nilainya berada di bawah range $3.5 \%-5 \%$. Hal ini disebabkan karena jumlah prosentase keramik yang ditambahkan, akan menurunkan nilai berat jenis gabungan campuran sehingga meningkatkan kerapatan campuran beton aspal.

Nilai Void Filled with Asphalt (VFWA) meningkat dengan penambahan keramik, grafik dapat dilihat pada Gambar 7. Pada pengujian campuran beton aspal yang tidak menggunakan variasi keramik menunjukkan nilai VFWA lebih kecil daripada nilai VFWA pada campuran yang menggunakan variasi keramik. Penambahan keramik akan menurunkan berat jenis gabungan campuran sehingga akan meningkatkan volume dan kerapatan campuran beton aspal. Kerapatan campuran menyebabkan jumlah rongga dalam campuran semakin sedikit dan dengan jumlah aspal yang sama, maka rongga-rongga udara yang terisi aspal semakin meningkat.

Pada Gambar 8, nilai Void in Mineral Agregate (VMA) akan menurun seiring dengan penambahan keramik. Hal ini disebabkan karena kerapatan campuran semakin bertambah disebabkan karena volume campuran semakin besar dan agregat akan semakin penuh mengisi campuran dan mengurangi rongga-rongga yang nantinya 
akan diisi oleh udara dan aspal. Nilai VMA yang tinggi mengakibatkan campuran memiliki stabilitas rendah (Nikmatul, 2017), dan sebaliknya jika nilai VMA semakin menurun maka campuran akan tahan terhadap deformasi jika menerima beban lalulintas.

Berdasarkan Gambar 9, nilai density mengalami penurunan dengan penambahan keramik. Penambahan keramik dalam campuran beton aspal akan meningkatkan kerapatan campuran, karena keramik yang digunakan dalam penelitian terdiri dari 3 ukuran yaitu tertahan saringan no.50, no.100 dan no.200, sehingga keramik mampu mengisi rongga-rongga dalam campuran.

Perendaman mempengaruhi karakteristik campuran akibat perubahan suhu, cuaca, dan air, dengan perendaman selama 0,5 jam dan rendaman selama 24 jam dapat dilihat pada Gambar 10 dan grafik nilai Index of Retained Strength (IRS) dapat dilihat pada Gambar 11.

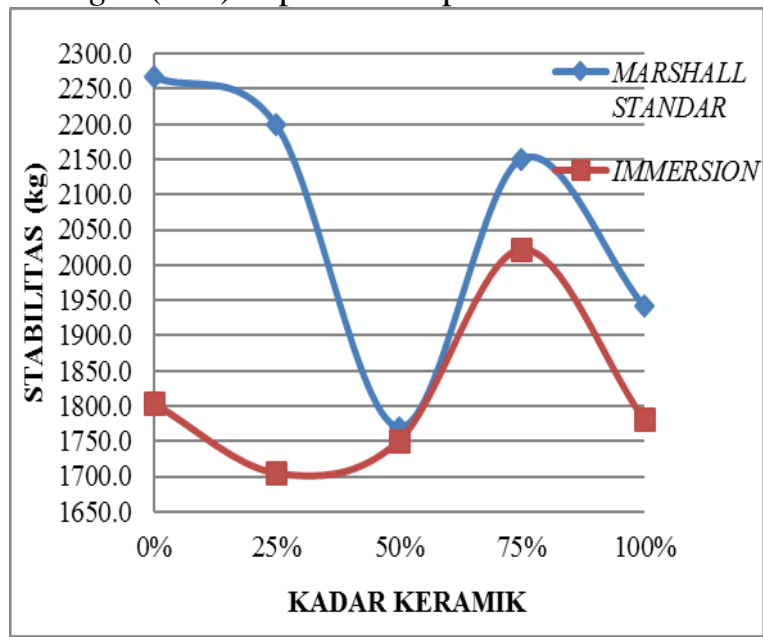

Gambar 10 Grafik Hubungan Variasi Kadar Keramik dengan Nilai Stabilitas pada Pengujian Marshall Standar dan Immersion

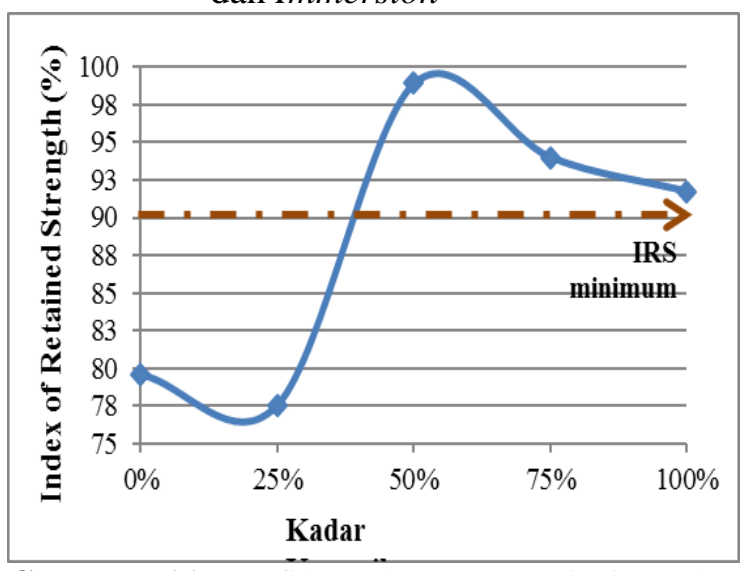

Gambar 11 Grafik Hubungan Variasi Kadar Keramik dengan Nilai Index of Retained Strength
Perkerasan jalan yang menggunakan Liqiud Asbuton untuk Lataston HRS-WC dapat tahan terhadap suhu dan lamanya perendaman dalam air (Londongsalu, Agus Tolla dkk, 2019). Berdasarkan grafik pada Gambar 10, dapat diketahui bahwa nilai stabilitas pada rendaman 24 jam lebih rendah dibandingkan dengan rendaman 30 menit. Hal ini disebabkan pada proses perendaman, air masuk ke dalam pori-pori campuran sehingga mengurangi ikatan adhesi antara aspal dan agregat. Campuran beton aspal dengan variasi $50 \%$ keramik tidak memenuhi syarat karena nilai stabilitas pada pengujian immersion $<75 \%$ dari nilai stabilitas Marshall standar.

Berdasarkan Gambar 11, perhitungan Index of Retained Strength untuk mengetahui kekuatan dan kekakuan yang dimiliki campuran setelah mengalami proses perendaman, dapat dilihat bahwa nilai IRS meningkat dengan penambahan keramik. Campuran beton aspal dengan variasi 50\% keramik, $75 \%$ keramik dan $100 \%$ keramik memiliki nilai IRS > 90\%. Hal ini disebabkan karena semakin banyak keramik yang ditambahkan dalam campuran meyebabkan menurunnya berat jenis gabungan campuran sehingga akan meningkatkan kerapatan campuran tersebut. Meningkatnya kerapatan campuran mengakibatkan nilai VITM yang rendah sehingga campuran memiliki rongga udara yang kecil dan campuran lebih kedap air. Lapisan aspal yang kedap air mampu menahan rembesan air yang masuk ke lapisan pondasi di bawahnya sehingga dapat mempengaruhi struktur bawahnya (Laia, Sandro dkk, 2016).

\section{PENUTUP}

Berdasarkan hasil penelitian dan perhitungan dari karakteristik campuran $\mathrm{Hot}$ Rolled Sheet-Wearing Coarse (HRS-WC) dengan variasi campuran beton aspal yang menggunakan variasi agregat halus dan filler keramik, maka dapat diambil simpulan sebagai berikut ini.

1. Campuran HRS-WC yang telah ditambahkan variasi keramik, mengalami perubahan pada karakteristik Marshall. Apabila ditarik garis linear berdasarkan gambar grafik karakteristik Marshall, maka nilai stabilitas, Marshall Quotient, VITM, VMA, menurun dengan penambahan keramik, sedangkan nilai 
flow, VFWA, density meningkat seiring dengan penambahan keramik.

2. Keramik layak dan dapat digunakan sebagai bahan tambahan agregat halus dan filler dalam campuran HRS-WC. Variasi kadar keramik yang baik digunakan yaitu campuran HRS-WC dengan variasi kadar 25\% keramik Hal ini dikarenakan, semua karakteristik Marshall telah memenuhi syarat spesifikasi Bina Marga 2009. Nilai flow pada campuran HRS-WC dengan variasi kadar 0\% keramik dan 50\% keramik tidak memenuhi syarat spesifikasi, karena campuran tersebut kaku dan mudah retak. Sedangkan campuran dengan variasi kadar $75 \%$ keramik semen dan $100 \%$ keramik memiliki rongga yang sangat sedikit, terlihat dari nilai VITM yang tidak memenuhi range syarat spesifikasi Bina Marga 2009 yaitu 3.5\% $5 \%$.

\section{DAFTAR PUSTAKA}

Arief, M. S. (2013). Penggunaan Bahan Pengisi (Filler) Serbuk Keramik, Ditinjau dari Parameter Marshall pada Lapis Aspal Beton (Laston). Jurnal Rekayasa Sipil, Universitas Islam Malang, 28-35.

Bina Marga, D. J. (1998). Manual Central Quality Control and Monitoring Unit. Jakarta: Departemen Pekerjaan Umum.

Bina Marga, D. J. (2009). Manual Konstruksi dan Bangunan Pemeriksaan Material/Bahan Jalan No.015/BM/2009. Jakarta: Departemen Pekerjaa Umum.

Kalbu, T. I. (2020). Lebih Dalam Mengenal Jenis Keramik dan Seluk Beluknya. Retrieved from Klasika Kompas: http://klasika.kompas.id/

Laia, Sandro dkk. (2016). Pengaruh Penggunaan Serbuk Keramik sebagai Tambahan Agregat Halus dalam Campuran Aspal. Jurnal Teknik dan Ilmu Komputer, Universitas Kristen Krida Wacana, 149-156.

Londongsalu, Agus Tolla dkk. (2019). Karakteristik Campuran Hot Rolled Sheet Wearing Course yang Menggunakan Batu dari Buntao Toraja Utara. E-Junal Teknik Sipil UKI-Paulus Makassar.
Nikmatul, A. (2017). Kinerja Campuran Hot Rolled Sheet-Wearing Course (HRSWC) dengan Filler Abu Ampas Tebu. Jurnal Bangunan, Universitas Negeri Malang, 11-20.

Revisdah, R. U. (2018). Pemanfaatan Limbah Keramik Terhadap Kuat Tekan Beton. Seminar Nasional Sains dan Teknologi, Universitas Muhammadiyah Jakarta.

(1991). SNI 06-2489. Pustran Balitbang, Pekerjaan Umum.

Sukirman, S. (1999). Perkerasan Jalan Lentur. Bandung: Nova.

Sukirman, S. (2012). Beton Aspal Campuran Panas. Bandung: Institusi Teknologi Bandung. 